\title{
Extracellular compounds produced by fungi associated with Botryosphaeria dieback induce differential defence gene expression patterns and necrosis in Vitis vinifera cv. Chardonnay cells
}

\author{
M. Ramírez-Suero • M. Bénard-Gellon • J. Chong • \\ H. Laloue • E. Stempien • E. Abou-Mansour • \\ F. Fontaine - P. Larignon - F. Mazet-Kieffer - S. Farine • \\ C. Bertsch
}

\begin{abstract}
Three major grapevine trunk diseases, esca, botryosphaeria dieback and eutypa dieback, pose important economic problems for vineyards worldwide, and currently, no efficient treatment is available to control these diseases. The different fungi associated with grapevine trunk diseases can be isolated in the necrotic wood, but not in the symptomatic leaves. Other factors seem to be responsible for the foliar symptoms and may represent the link between wood and foliar symptoms. One hypothesis is that the extracellular compounds produced by the fungi associated with grapevine trunk diseases are responsible for pathogenicity.
\end{abstract}

Ramírez-Suero and Bénard-Gellon contributed equally to this work.

M. Ramírez-Suero • M. Bénard-Gellon · J. Chong $\cdot$ H. Laloue • E. Stempien $\cdot$ F. Mazet-Kieffer $\cdot$ S. Farine $\cdot$ C. Bertsch $(\varangle)$

Laboratoire Vigne Biotechnologie et Environnement EA 3991, Université de Haute-Alsace, 33, rue de Herrlisheim, BP 68008,

Colmar Cedex, France

e-mail: christophe.bertsch@uha.fr

E. Abou-Mansour

Département De Biologie Végétale, Université de Fribourg,

10 Chemin du Musée, 1700 Fribourg, Switzerland

F. Fontaine

Unité de Recherche Vignes et Vins de Champagne EA 4707 (URVVC), Laboratoire Stress Défenses et Reproduction des Plantes (SDRP), Université de Reims Champagne Ardenne, UFR Sciences Exactes et Naturelles, Moulin de la Housse, BP 1039, 51687 Reims Cedex 2, France

P. Larignon

Institut Français de la Vigne et du Vin, Pôle Rhône-Méditerranée,

Domaine de Donadille, 30230 Rodilhan, France
In the present work, we used Vitis vinifera $\mathrm{cv}$. Chardonnay cells to test the aggressiveness of total extracellular compounds produced by Diplodia seriata and Neofusicoccum parvum, two causal agents associated with botryosphaeria dieback. Additionally, the toxicity of purified mellein, a characteristic toxin present in the extracellular compounds of Botryosphaeriaceae, was assessed.

Our results show that the total extracellular compounds produced by $N$. parvum induce more necrosis on Chardonnay calli and induce a different defence gene expression pattern than those of $D$. seriata. Mellein was produced by both fungi in amounts proportional to its aggressiveness. However, when purified mellein was added to the culture medium of calli, only a delayed necrosis and a lower-level expression of defence genes were observed. Extracellular compounds seem to be involved in the pathogenicity of the fungi associated with botryosphaeria dieback. However, the doses of mellein used in this study are 100 times higher than those found in the liquid fungal cultures: therefore, the possible function of this toxin is discussed.

Keywords Vitis vinifera cells (calli) · Fungal phytotoxins · Extracellular compounds · Defence gene expression · Diplodia seriata $\cdot$ Neofusicoccum parvum

\begin{tabular}{ll}
\multicolumn{2}{l}{ Abbreviations } \\
RT-qPCR & Reverse transcription quantitative real-time PCR \\
Pal & Phaeoacremonium aleophilum \\
Pch & Phaemoniella chlamydospora \\
Fme & Fomitiporia mediterranea \\
GST1 & Glutathion-S-transferase 1 \\
SOD & Superoxyde dismutase \\
AOS & Allene oxyde synthase
\end{tabular}




$\begin{array}{ll}\text { LOX } & \text { Lipo-oxygenase } \\ \text { F3H } & \text { Flavonoid-3-hydroxylase } \\ \text { FMT } & \text { Flavonoid-O-methyltransferase } \\ \text { PAL } & \text { Phenylalanine amonia-lyase } \\ \text { STS1 } & \text { Stilbene synthase 1 } \\ \text { PR6 } & \text { Pathogenesis related protein } 6 \\ \text { GLU } & \text { Glucanase } \\ \text { CHIT4c } & \text { Chitinase 4c } \\ \text { PR10.1 } & \text { Pathogenesis-related protein 10.1 } \\ \text { HSR } & \text { Hypersensitive response } \\ \text { ACT } & \text { Actine } \\ \text { EF1-Cs } & \text { Elongation factor 1-Cabernet sauvignon }\end{array}$

\section{Introduction}

Three major grapevine trunk diseases (esca, botryosphaeria dieback and eutypa dieback) are considered very harmful to the sustainability of viticultural heritage. The scientific community assigns the symptoms of these diseases to one or several xylem-inhabiting fungi that attack the perennial organs of grapevine, leading to leaf and berry symptoms and essentially causing long-term death of the plant (for review, see Bertsch et al. 2013). Phaeomoniella chlamydospora (Crous and Gams 2000), Phaeoacremonium aleophilum (Crous et al.1996), Eutypa lata (Rappaz 1984), Fomitiporia mediterranea (Fischer 2002) and several members of the Botryosphaeriaceae are the main species that have been associated with these diseases worldwide. The frequency of disease symptoms has increased considerably over the past few decades (Bruez et al. 2013). Traditionally, sodium arsenite has been the only potentially effective treatment against fungal trunk diseases (Larignon 2004; Bisson et al. 2006; Spinosi and Févotte 2008); however, the use of this compound was banned in 2001 due to its toxicity towards humans and the environment. The lack of alternative strategies to fight these diseases could exacerbate the situation. In the field, the expression of foliar symptoms of fungal trunk diseases seems to differ in different Vitis vinifera cultivars (Grossman and Doublet 2012; Bruez et al. 2013). For example, Chardonnay infected by trunk disease-causing agents presents less symptomatic leaves compared with other cultivars. To date, no resistant cultivar has been reported (Surico et al. 2006; Larignon et al. 2009).

Botryosphaeria dieback, or black dead arm, which other authors have also associated with esca disease, has been reported since the 1970 and is caused by Botryosphaeriaceae species such as Diplodia mutila (teleomorph form: Botryosphaeria stevensii, Shoemaker 1964), Diplodia seriata (teleomorph form: Botryosphaeria obtusa (Schwein.), Shoemaker 1964) (Lehoczky 1974; Cristinzio 1978) and later with Neofusicoccum parvum (teleomorph form: Botryosphaeria parva) (Pennycook and Samuels 1985). Botryosphaeriaceae species have been found in vineyards in several countries, for example, Italy, France, Germany, Chile, Spain, Hungary, Lebanon and China (Larignon et al. 2009; Bertsch et al. 2013; Yan et al. 2013). Typical symptoms vary between white grapevine cultivars and red ones. White cultivars present yellowish-orange spots on the leaf margins and the blade, whereas red cultivars show wine-red spots. In both cases, the wood of the infected grapevines exhibits necrosis (Rovesti and Montermini 1987; Larignon et al. 2001). A cross in the wood shows a yellow to orange area at the edge of a brown band, limited to a few millimetres in depth, where the vessels are clogged. In woody tissue, grey sectorial necrosis can be observed, and this is equivalent to black dots on a cross (Larignon 2012). Given that pathogens can be found in the wood but never in the leaves of infected plants, it was hypothesised that the observed leaf and berry symptoms are actually caused by extracellular compounds produced by fungi in the discoloured woody tissues of the trunk, which then translocate to the leaves via the transpiration stream (Mugnai et al. 1999). Botryosphaeriaceae produces phytotoxic metabolites whose synergic activities could lead to the foliar symptoms observed on grapevines; however, the cause of these symptoms and the role of these metabolites in disease development remain unclear (Andolfi et al. 2011). Since the 1990s, some of the Botryosphaeriaceae phytotoxic metabolites have been isolated and characterised both chemically and biologically (for review, see Andolfi et al. 2011). Some earlier research identified phytotoxic exopolysaccharides that are secreted by botryosphaeriaceous fungi (Martos et al. 2008), and more recently, two studies identified additional toxic compounds: mellein, cis- and trans-4-hydroxymellein, 4,7dihydroxymellein, isosclerone and tyrosol (Djoukeng et al. 2009; Evidente et al. 2010). All of these compounds seem to exhibit a similar level of toxicity when tested on tomato and grapevine leaf discs, leading the authors to speculate that the production of these compounds may induce phytotoxic effects. Whereas isosclerone and tyrosol are produced by botryosphaeriaceous fungi and fungi causing esca; the melleins and their derivatives appear to be produced only by botryosphaeriaceous fungi. Moreover, Andolfi et al. (2011) proposed mellein as a good diagnostic marker of diseased plants.

No information concerning the effect of mellein and the total extracellular metabolites produced by Botryosphaeriaceae on grapevine cells is currently available. Further investigations are therefore needed to better understand the role that different extracellular compounds play in the expression of disease symptoms.

Studies on grapevine have been conducted at multiple levels: in naturally infected vineyards, under controlled conditions using greenhouse cuttings and with artificially infected in vitro grapevine model. Interestingly, only eutypa dieback symptoms have been reproduced using artificial infection (Petzoldt et al. 1981; Péros and Berger 1994; Sosnowski 
et al. 2007; Camps et al. 2010). In contrast, no studies have reported the artificial reproduction of foliar symptoms caused by esca or botryosphaeria dieback on grapevine. Therefore, because we lack a model corresponding to the real symptoms observed in the field, the most simplified model, i.e. cell culture, particularly the callus model, could be used as an alternative. Calli are composed of groups of undifferentiated grapevine cells. Calli or cell suspensions are often used to study the expression of defence-related genes in different diseases or to study the effect of elicitors. Even some studies concerning esca disease have used in vitro cultured cells (calli) to understand the inhibitory effect of toxins from $P$. aleophilum (teleomorph form: Togninia minima) or P. chlamydospora (teleomorph unknown) (Sparapano et al. 2001; Santos et al. 2005). Hence, it seems that this model allows us to study the different defence pathways from Vitis cells under controlled conditions.

The present work describes the effects of total extracellular compounds and purified mellein from different isolates of $D$. seriata and $N$. parvum on a simplified model using grapevine cells (calli) from $V$. vinifera cv. Chardonnay. The aim of this work was to evaluate the impact of total extracellular compounds produced by these fungi, as well as purified mullein, on both calli necrosis and defence gene expression.

\section{Material and methods}

Plant material

Calli of $V$. vinifera $\mathrm{cv}$. Chardonnay clone 96 were obtained from anthers as described in Mauro et al. (1986) and Bertsch et al. (2005).

All calli were subcultured every 3 weeks on MPM1 medi-

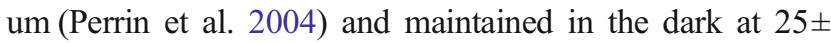
$0.5{ }^{\circ} \mathrm{C}$ with $70 \pm 10 \% \mathrm{RH}$. For each test condition, 30 whiteyellowish calli, with a diameter of $10 \pm 2 \mathrm{~mm}$, were used.

Fungal isolates and mellein toxicity

D. seriata strains 99.7 (Rhône-Alpes, France) and 98.1 (Pyrénées Orientales, France) and N. parvum strains Bt67 (Estremadura, Portugal) and Bourgogne S-116 (Bourgogne, France) were isolated from vineyards.

All strains were grown on Petri dishes containing PDA solid medium at $26^{\circ} \mathrm{C}$ for 10 days, in the dark. These cultures were used to prepare liquid cultures grown in $250 \mathrm{ml}$ of malt medium $\left(20 \mathrm{gL}^{-1}\right)$ at $220 \mathrm{rpm}$ and $28{ }^{\circ} \mathrm{C}$ and in the dark.

Fourteen days after incubation, the fungal culture medium was centrifuged for $8 \mathrm{~min}$ at $11,000 \mathrm{rpm}$ at $25{ }^{\circ} \mathrm{C}$ in an Eppendorf $^{\circledR}$ centrifuge 5804R. Culture medium supernatant was recovered and filtered through $0.20 \mu \mathrm{m}$ membranes to eliminate spores and sterilise the solution. After optimisation of the calli culture conditions, the culture medium filtrate from each fungus was incorporated into the MPM1 calli medium at a concentration of $40 \%(v / v$ - sublethal concentration), at $25{ }^{\circ} \mathrm{C}, \mathrm{pH} 6$ and in the dark, and 3-week-old $V$. vinifera $\mathrm{cv}$. Chardonnay calli were subcultured.

Mellein toxin was isolated from $D$. seriata isolate F-99.2 (Djoukeng et al. 2009). Three-week-old V. vinifera cv. Chardonnay calli were subcultured in MPM1 solid medium (Perrin et al. 2004) with mellein at 25, 200 and $500 \mu \mathrm{g} \mathrm{ml}^{-1}$. Calli were incubated at $28^{\circ} \mathrm{C}$ in the dark using a Memmerto ${ }^{\mathrm{TM}}$ incubator.

The toxicity of the extracellular compounds or mellein was assessed visually as the appearance of necrosis on the calli at $0,1,3$ and 6 days, and calli were collected for defence gene expression analysis. Five calli (from five different Petri dishes) were collected for each condition and at each time. Two biological replicates were performed for each experiment.

\section{Mellein analyses on filtrates}

Extracellular compounds produced by the four isolates were sampled at 14 days (medium without fungus was used as a control), filtered through $0.20 \mu \mathrm{m}$ membranes, and $200 \mu \mathrm{l}$ of the filtrate was submitted to analysis. Chromatographic analyses were carried out using a MN Nucleosil100-5 C18 column (250 nm $\times 4$ id) (Düren, Germany). The mobile phase consisted of two solvents: water/acetic acid (1\%) (A) and acetonitrile (B). The linear gradient started at $5 \% \mathrm{~B}$ and increased to $70 \%$ in $30 \mathrm{~min}$ and $100 \%$ in $35 \mathrm{~min}$. The flow rate was $1 \mathrm{ml} \cdot \mathrm{min}^{-1}$, and the injection volume was $200 \mu \mathrm{l}$. Spectral data from all peaks were accumulated in the range between 220 and $400 \mathrm{~nm}$, and chromatograms were recorded at $320 \mathrm{~nm}$ for mellein. The LC/UV-DAD analysis was carried out on a Thermo Scientific Dionex HPLC with an Ultimate 3000 diode array detector. The mellein concentration was calculated according to an external calibration curve (Djoukeng et al. 2009).

Gene expression analysis by real-time quantitative RT-PCR

Calli were harvested in liquid nitrogen at $0,1,3$ and 6 days after being subcultured on medium supplemented with extracellular compounds from fungi or with mellein alone and stored at $-80{ }^{\circ} \mathrm{C}$. Total RNA was extracted using the RNeasy Plant Mini Kit (Qiagen ${ }^{\circledR}$ ), following the manufacturer's instructions; RNA concentration was determined with a Qubit fluorometer (Invitrogen ${ }^{\circledR}$ ). One microgram of total RNA was incubated with one unit of RNase-free DNaseI (Euromedex ${ }^{\circledR}$ ) for $30 \mathrm{~min}$ at $37{ }^{\circ} \mathrm{C}$ according to the manufacturer's instructions. cDNA was synthesised from RNA using the SuperScript II Reverse Transcriptase (Invitrogen ${ }^{\circledR}$ ). 
Quantitative PCR was performed on a CFX 96 real-time PCR system with a C1000 thermal cycler (Bio-Rad $\left.{ }^{\circledR}\right)$. The primers listed in Table 1 are designed from genes for cellular detoxification ( $V v G S T 1, V v S O D)$, the jasmonic acid pathway $(V v A O S, V v L O X)$, the synthesis of secondary metabolites of the phenylpropanoid pathway $(V v P A L)$, the phytoalexins pathway $(V v S T S 1)$, the flavonoid pathway $(V v F 3 H, V v F M T)$, the pathogenesis-related proteins ( $V v P R 6, V v G L U, V v C H I T 4 c$, $V v P R 10.1)$ and the hypersensitive response ( $V v H S R)$.

Three technical and two biological replicates were performed for each gene in a total volume of $25 \mu$ containing $12.5 \mu \mathrm{l}$ of SYBR Green Mastermix (Euromedex ${ }^{\circledR}$ ), $0.5 \mu \mathrm{l}$ of each primer at $10 \mu \mathrm{M}$ and $10 \mathrm{ng}$ of cDNA, with the following thermal cycling conditions: $3 \mathrm{~min}$ at $95{ }^{\circ} \mathrm{C}$ followed by 40 cycles of $15 \mathrm{~s}$ at $95^{\circ} \mathrm{C}, 15 \mathrm{~s}$ at $60{ }^{\circ} \mathrm{C}, 20 \mathrm{~s}$ at $72{ }^{\circ} \mathrm{C}$ and $10 \mathrm{~s}$ at $77^{\circ} \mathrm{C}$. At the end of the final PCR cycle, a heat dissociation curve from 60 to $95{ }^{\circ} \mathrm{C}$ was used to check the specificity of the individual PCR.

The data were analysed using CFX Manager software, and the relative levels of gene expression were determined following the method of Hellemans et al. (2007) with $V v A C T$ and $V v E F 1-C s$ serving as the two internal reference genes. Gene expression was defined as an induction ratio higher than 4 .

Statistical analysis

Mean values and standard deviations for the mellein analyses were obtained from two samples of extracellular compounds produced by both fungi during two different years (2011 and 2012). For gene expression analysis by RT-qPCR, five calli (one per plate) were taken for each condition at each time $(0$, 1, 3 and 6 days contact) for each experiment. Mean values and standard deviations were obtained according to Hellemans et al. (2007). Each data point represents the mean of three technical and two biological replicates. Error bars represent the standard error of the mean. The Duncan test (at $p \leq 0.05-$ Duncan 1955) and multifactorial ANOVA (StatgraphicPlus ${ }^{\circledR}$ Manugistics, Inc., Maryland, USA) were performed to compare gene expression (induction ratio) on each day for each fungus, for the different tested times for both fungi and to compare the fungi. OriginPro $7.5^{\circledR}$ software was used to plot the data.

\section{Results}

Extracellular compounds from the different fungal isolates induced variable necrosis and defence gene expression in subcultured calli

None of the extracellular compounds from the fungi induce necrosis in calli after 1 day. The first effects (necrosis) of the extracellular compounds from the two $N$. parvum isolates and from D. seriata 99.7 are observed on calli after 3 days of contact, and a slight necrotic effect from those of $D$. seriata 98.1 appears after 6 days of contact. Extracellular compounds from $N$. parvum Bourgogne S-116 seem more aggressive than those from the other fungal isolates tested, as all calli were necrotic after 3 days (data not shown).

When $V$. vinifera cv. Chardonnay calli were subcultured with extracellular compounds produced by $N$. parvum isolate Bourgogne S-116 for 6 days, total necrosis appeared in all calli (Fig. 1a), whereas extracellular compounds from N. parvum isolate Bt67 only induced partial necrosis. Only a few of the calli subcultured with extracellular compounds from this isolate were totally necrotic (Fig. 1b). Two isolates of $D$. seriata (98.1 and 99.7) were also tested and their extracellular compounds induced partial necrosis of the calli (Figs. 1c, d).

Table 1 Sequences of the primers derived from Vitis vinifera and used for RT-qPCR

\begin{tabular}{|c|c|c|c|}
\hline Gene & Gene bank accession number & Forward primers $\left(5^{\prime} \rightarrow 3^{\prime}\right)$ & Reverse primers $\left(5^{\prime} \rightarrow 3^{\prime}\right)$ \\
\hline VvActin & AF369524 & TGCTATCCTTCGTCTTGACCTTG & GCACTTCTGGACAACGGAATCTC \\
\hline$V v E F 1-C s$ & CB977561 & ACTCCAAGGCAAGGTACGATGATGA & GGGGACAAATGGAATCTTATC \\
\hline$V v G S T 1$ & AY156048 & CAAGGCTATATCCCCATTTTCTTC & TGCATGGAGGAGGAGTTCGT \\
\hline$V v S O D$ & AF056622 & TGCCAGTGGTAAGGCTAAGTTCA & GTGGACCTAATGCAGTGATTGA \\
\hline$V v H S R$ & AF487826 & GGACTACCGACATGCACCTG & CCTGGACAATTCTGCCATCT \\
\hline$V v A O S$ & NCBI reference sequence, XP_002283780.1 & GCCTGGCTTAATCACGACAT & CACCTTCGTCCAGAACATGA \\
\hline$V v L O X$ & FJ858256 & СССТTCTTGGCATCTCCCTTA & TGTTGTGTCCAGGGTCCATTC \\
\hline$V v P A L$ & X75967 & TCCTCCCGGAAAACAGCTG & TCCTCCAAATGCCTCAAATCA \\
\hline VvSTS1 & DQ366301 & TACGCCAAGAGATTATCACT & CTAAAGAGTCCAAAGCATCT \\
\hline$V v F 3 H$ & XM_002284129.1 & ATCGTGGAGGAGCACAAGAT & TGGATGAGGTGTCAGTTCCA \\
\hline$V v P R 6$ & AY156047 & AGGGAACAATCGTTACCCAAG & CCGATGGTAGGGACACTGAT \\
\hline$V v G L U$ & AF239617 & ATGCTGGGTGTCCCAAACTCG & CAGCCACTCTCCGACAGCAC \\
\hline VvCHIT4c & AY137377 & TCGAATGCGATGGTGGAAA & TCCCCTGTCGAAACACCAAG \\
\hline VvPR10.1 & AJ291705 & CTGTGGTTGACGGAGATGTT & СССТTAACGTGCTCTTCAGAG \\
\hline
\end{tabular}




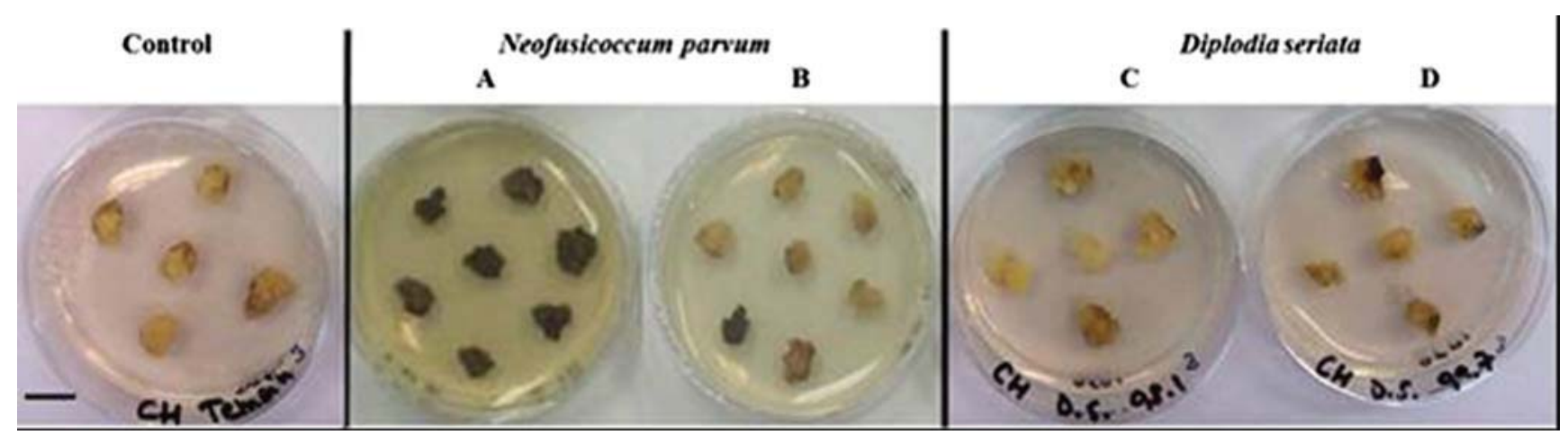

Fig. 1 Calli subcultured in Petri dishes with malt medium (control) or extracellular compounds from N. parvum strains Bourgogne S-116 (a), Bt67 (b) and D. seriata strains 98.1 (c) and 99.7 (d) after 6 days. Bar corresponds to $10 \mathrm{~mm}$

To complement these visual observations, the induction of defence mechanisms by fungal extracellular compounds was evaluated in $V$. vinifera calli. The expression of several genes was studied (Table 1): the genes participating in cellular detoxification ( $V v G S T 1, V v S O D)$, the jasmonic acid pathway $(V v A O S, V v L O X)$, synthesis of secondary metabolites of the phenylpropanoid pathway $(V v P A L)$, phytoalexin production ( VvSTS1), flavonoid synthesis $(V v F 3 H, V v F M T)$, pathogenesis-related proteins ( $V v P R 6, V v G L U, V v C H I T 4 c$ and $V v P R 10.1)$ and the hypersensitive response ( $V v H S R)$.

Our results indicate that extracellular compounds from $D$. seriata isolates do not induce the expression of the genes tested (induction ratio <4), after 1 day (Fig. 2a, b). Extracellular compounds from $D$. seriata isolate 98.1 significantly induced $(p \leq 0.0001)$ the expression of genes for cellular detoxification ( $V v G S T 1)$, phenylpropanoid enzymes $(V v P A L)$, phytoalexin ( $V v S T S 1)$ pathways and PR-proteins ( $V v P R 6, V v C h i t 4 c$ and $V v P R 10.1$ ) after 3 days (Fig. 2a); those of $D$. seriata isolate 99.7 significantly induced $(p \leq 0.0001)$ a lower degree of expression of the same, as well as another gene encoding a PR-protein $(V v G L U)$ (Fig. 2b). After 6 days, the extracellular compounds of isolate 98.1 induced significant but low expression of genes participating in the jasmonic acid pathway $(V v A O S)$ and those encoding PR-proteins ( $V v C H I T 4 c$ and $V v P R 10.1)$ (Fig. 2a), and compounds of isolate 99.7 significantly induced $(p \leq 0.0001)$ the expression of only one PR-protein gene ( $V v C h i t 4 c)$ (Fig. 2b). At this time, defence gene expression was significantly $(p \leq 0.05)$ lower than after 3 days of contact.

After 1 day, the extracellular compounds of the $N$. parvum Bt67 isolate (Fig. 2c) significantly induced $(p \leq 0.0001)$ the expression of $V v G S T 1, V v P A L, V v S T S 1, V v C H I T 4 c$, $V v P R 10.1$ and $V v H S R$ (hypersensitive response); compounds of the Bourgogne S-116 isolate (Fig. 2d) induced VvGST1, $V v L O X$ (jasmonic acid pathway), VvPR6, VvCHIT4c and $V v P R 10.1$ to a significantly $(p \leq 0.05)$ lower extent than the other isolate. The number of induced defence gene increased after 3 days, with extracellular compounds from the Bt67 isolate; thus, nine genes ( $V v G S T 1, V v L O X, V v P A L, V v S T S 1$,
VvPR6, VvGLU, VvCHIT4c, VvPR10.1 and VvHSR) were significantly $(p \leq 0.0001)$ induced compared to 1 day of contact (Fig. 2c). After 6 days of contact, the relative expression levels of the genes decreased, but 11 genes ( $V v G S T 1, V v L O X$, $V v P A L, V v S T S 1, V v F 3 H, V v F M T$ (2 genes involved in the flavonoid pathway) $V v P R 6, V v G L U, V v C H I T 4 c, V v P R 10.1$ and $V v H S R$ ) were induced (Fig. 2c). The extracellular compounds from the Bourgogne S-116 isolate significantly induced $(p \leq 0.0001)$ fewer genes (VvGST1, VvFMT, $V v C H I T 4 c$ and $V v P R 10.1)$ after 3 days, with a significantly $(p \leq 0.05)$ lower induction ratio than after 1 day. However, this ratio significantly increased $(p \leq 0.05)$ after 6 days, revealing the expression of seven genes ( $V v G S T 1, V v P A L, V v S T S 1$, $V v P R 6, V v C H I T 4 c, V v P R 10.1, V v H S R)$ at this time (Fig. 2d). In summary, Bourgogne S-116 extracellular compounds induced significantly $(p \leq 0.05)$ lower defence gene expression than the extracellular compounds of the Bt67 isolate at the different times and showed different kinetics of defence gene expression compared with the other three fungi. Overall, the extracellular compounds of the two $N$. parvum isolates induced significantly $(p \leq 0.05)$ more defence gene expression, with a higher induction ratio, compared with those produced by $D$. seriata at the different tested times, except after 3 days of contact with extracellular compounds from N. parvum Bourgogne S-116.

\section{Mellein analyses}

We focused our analyses on mellein which is a characteristic toxin of the Botryosphaeriaceae. The culture medium of the four fungi was centrifuged, and the supernatant was filtered and analysed by HPLC.

The results indicated that the culture media of $N$. parvum isolates Bourgogne S-116 and Bt67 produced 4.26 $0.08 \mu \mathrm{g} \mathrm{ml}^{-1}$ and $1.20 \pm 0.34 \mu \mathrm{g} \mathrm{ml}^{-1}$ mellein, respectively. In the culture medium of $D$. seriata isolate 99.7 a very low concentration of mellein was measured $\left(0.40 \pm 0.46 \mu \mathrm{g} \mathrm{ml}^{-1}\right)$, and no mellein was detected in the medium of isolate 98.1 (Table 2). 
a

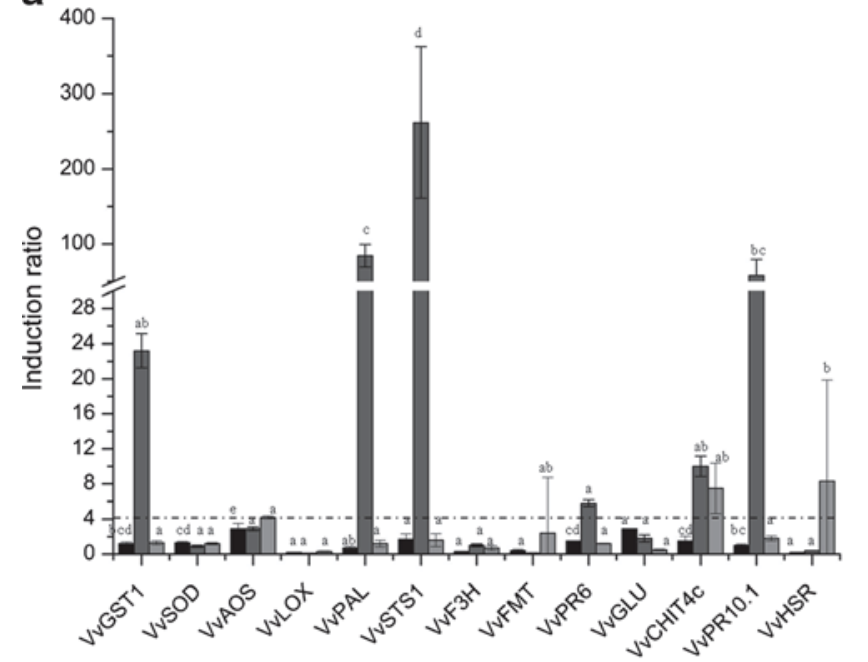

C

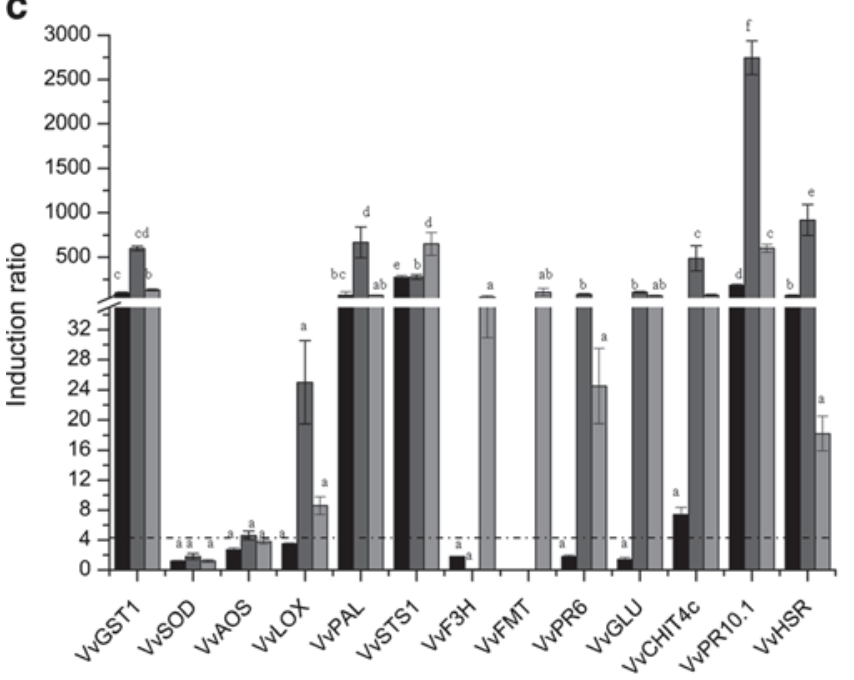

b

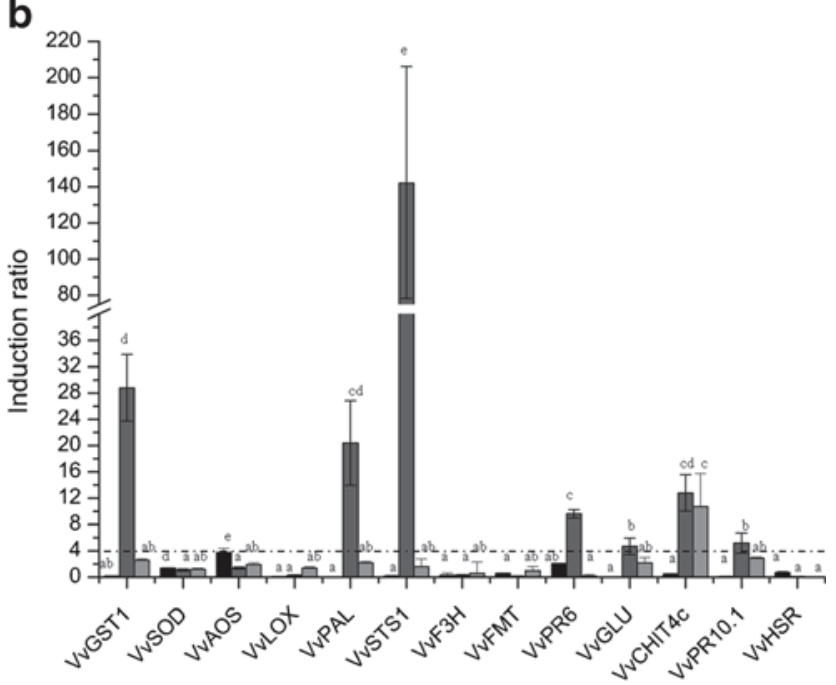

d

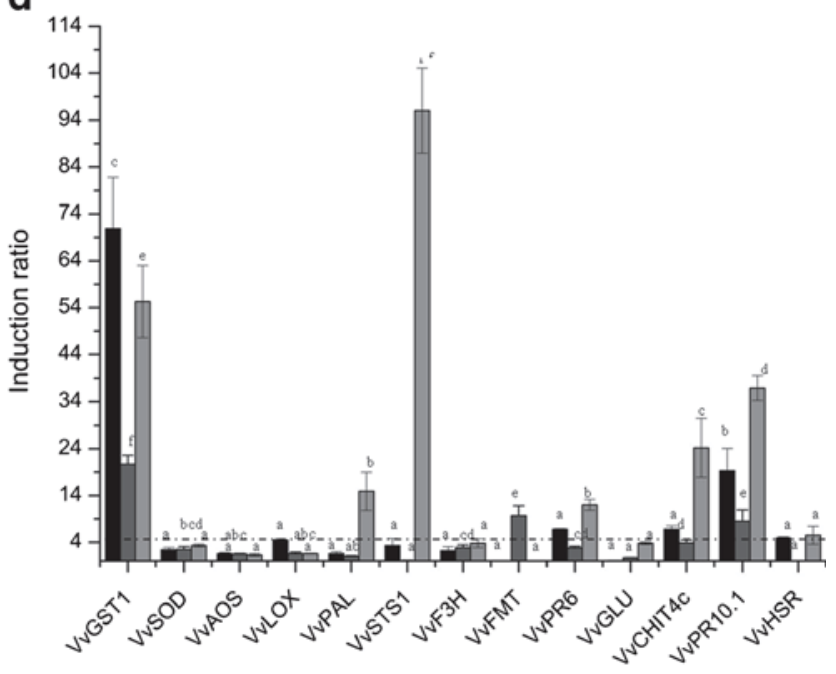

Values (means \pm STD) with dissimilar letters in the same color columns are significant at $\mathrm{P} \leq 0.0001$ or $\mathrm{P} \leq 0.01$ (only on graph $\mathrm{A}$ with grey columns)

Fig. 2 Defence gene expression in calli of $V$. vinifera cv. Chardonnay subcultured in Petri dishes with total extracellular compounds from D. seriata strains 98.1 (a) and 99.7 (b) and N. parvum strains Bt67 (c) and Bourgogne S-116 (d) after 1 (black), 3 (medium grey) and 6 (grey) days. Gene expression was assessed by RT-qPCR. The results represent the relative expression in calli grown on different media containing fungal compounds versus those grown on malt medium (control). The genes tested encode cellular detoxification enzymes ( $V v G S T 1, V v S O D)$, jasmonic acid pathway enzymes ( $V v A O S, V v L O X)$, enzymes for secondary metabolites of the phenylpropanoid pathway $(V v P A L)$, phytoalexins pathway enzymes $(V v S T S 1)$, flavonoid pathway enzymes $(V v F 3 H$, $V v F M T)$, pathogenesis-related proteins ( $V v P R 6, V v G L U, V v C H I T 4 \mathrm{c}$, $V v P R 10.1)$ and hypersensitive response $(V v H S R)$. Each data point represents the mean of 3 technical and 2 biological replicates. Error bars represent the standard error of the mean. The dotted line corresponds to an induction ratio $=4$

\section{Gene responses of calli to mellein}

To evaluate the toxic effects of mellein, the purified toxin, which was previously isolated from the liquid culture media of $D$. seriata, was added at different concentrations $\left(25,200\right.$ and $\left.500 \mu \mathrm{g} \mathrm{ml} \mathrm{ml}^{-1}\right)$ to the MPM1 calli medium. Mellein added to the MPM1 media at 25 and $200 \mu \mathrm{g} \mathrm{ml}^{-1}$ did not induce any necrosis at 1,3 and 6 days (data not shown). However, at $500 \mu \mathrm{g} \mathrm{ml}^{-1}$, slight and partial necrosis was observed on calli after 6 days of contact (Fig. 3).
Defence gene expression was also studied in all calli. The initial results showed that none of the tested genes were induced with $25 \mu \mathrm{g} \mathrm{ml}^{-1}$ mellein (data not shown). With higher mellein concentrations $\left(200\right.$ and $500 \mu \mathrm{g} \mathrm{ml}^{-1}$ ), no induction of the defence genes was observed after 1 day of contact (data not shown). A mellein concentration of $200 \mu \mathrm{g} \mathrm{ml}^{-1}$ also did not induce (induction ratio $<4$ ) defence gene expression, after 3 and 6 days (Fig. 4a). However, $500 \mu \mathrm{g} \mathrm{ml}{ }^{-1}$ mellein caused the significant induction $(p \leq 0.01)$ of one gene encoding PR-protein $(V v P R \sigma)$ after 3 days, and after 6 days, the expression of genes encoding 
Table 2 Concentrations of mellein $\left(\mu \mathrm{g} \mathrm{ml} l^{-1}\right)$ produced by fungi after 14 days of culture in liquid malt medium

\begin{tabular}{ll}
\hline Sample & $\begin{array}{l}\text { Mellein } \pm \text { standard deviation } \\
\left(\mu \mathrm{g} \mathrm{ml}^{-1}\right)\end{array}$ \\
\hline Np Bourgogne S-116 & $4.26 \pm 0.08^{\mathrm{a}}$ \\
Np Bt 67 & $1.20 \pm 0.34^{\mathrm{b}}$ \\
Ds 98.1 & $\mathrm{ND}$ \\
Ds 99.7 & $0.40 \pm 0.46^{\mathrm{c}}$ \\
Malt control & $\mathrm{ND}$ \\
\hline
\end{tabular}

$N D$ no detected

${ }^{\text {a,b,c }}$ Mean $( \pm$ STD) values followed by dissimilar letters in a row are significantly different at $p<0.05$

cellular detoxification enzymes ( $V v G S T 1)$, enzymes of the phenylpropanoid ( $V v P A L)$, phytoalexin $(V V S T S 1)$ and flavonoid $(V v F M T)$ pathways and PR-proteins $(V v P R 6, V v G L U$, $V v C H I T 4 c, V v P R 10.1)$ was significantly $(p \leq 0.01)$ induced (Fig. 4b). In summary, only $500 \mu \mathrm{g} \mathrm{ml}^{-1}$ mellein induced cell necrosis and defence gene expression (induction ratio $>4$ ).

\section{Discussion}

The main Botryosphaeriaceae species associated with botryosphaeria dieback in grapevine are $N$. parvum and $D$. seriata, but the role of their extracellular compounds and the impact of these compounds on grapevine remains unclear. These fungi produce a variety of compounds in their hosts as well as in artificial media, and some of these molecules have been characterised (for review, see Andolfi et al. 2011).

The effects of fungal extracellular compounds on defence gene expression in $V$. vinifer $a$ can be evaluated under different conditions: in the field, in greenhouses or in vitro. For this type of study, experiments in vineyards present some disadvantages because climate effects influence the homogeneity of

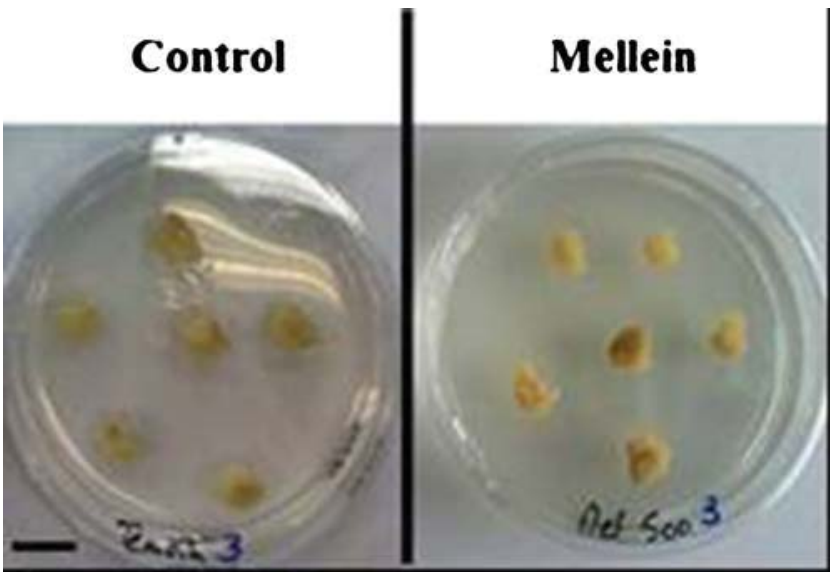

Fig. 3 Calli subcultured in Petri dishes with malt medium (control) and mellein at $500 \mu \mathrm{g} \mathrm{ml}^{-1}$ after 6 days of contact. Bar corresponds to $10 \mathrm{~mm}$ field-collected data and add to the difficulty of distinguishing the impact of fungi associated with grapevine trunk diseases from that of other biotic agents. The second possibility is to use artificial infection in greenhouses, but the difficulty of reproducing characteristic foliar symptoms hinders such studies. As a result, there are no models corresponding to the real symptoms observed in vineyards, and for this reason, we decided to use a simplified model: cell culture, particularly the callus model.

Calli are composed of undifferentiated groups of cells and can be easily obtained via somatic embryogenesis or shoot organogenesis. They are often used to study defence gene expression in different diseases or to study the effects of elicitors (Wielgoss and Kortekamp 2006; Lijavetzky et al. 2008). Some authors have also used this model to study the virulence of $P$. aleophilum and $P$. chlamydospora strains (Santos et al. 2005, 2006). In 2006, Bruno and Sparapano observed necrosis in $V$. vinifera $\mathrm{cv}$. Italia and $\mathrm{cv}$. Mathilde calli grown with extracellular compounds from three different esca-associated fungi, P. chlamydospora (Pch), Togninia minima (Tmi) and F. mediterranea (Fme) (Bruno and Sparapano 2006); however, defence gene expression was not analysed in this study. Therefore, this model seems to be optimal for studying the different defence pathways of Vitis cells.

In the present study, we were able to visually observe differential toxicity for the extracellular compounds produced by $N$. parvum or D. seriata towards calli of grapevine cv. Chardonnay. The extracellular compounds of $N$. parvum seem more virulent than those of $D$. seriata which is in agreement with results obtained by Martos et al. (2008), who showed greater phytotoxic activity for culture filtrates from $N$. parvum compared with D. seriata on grapevine leaves from cv. Tempranillo, though no analysis of defence responses was performed. Our calli test showed that total extracellular metabolites from $N$. parvum and D. seriata induced not only different levels of necrosis but also different gene expression profiles. We observed defence gene expression after 1 day with both $N$. parvum isolates and only after 3 days with $D$. seriata isolates. These molecular results correspond to our visual observations of calli as the different degrees of virulence for the extracellular compounds were specific to the fungal isolates studied. The total extracellular compounds from $N$. parvum Bourgogne S-116, which are responsible for the more rapid and complete necrosis of calli compared with those from $N$. parvum Bt67, produced a lower induction of defence genes. Moreover, the VvHSR gene, which is implicated in the hypersensitive response, was expressed at a lower level with extracellular compounds from the Bourgogne S-116 isolate compared with those from the Bt67 isolate. It is possible that the Bourgogne S-116 isolate could rapidly induce cell death in Vitis cells in a way different from hypersensitive cell death. This rapid cell death could explain the low induction of defence genes 

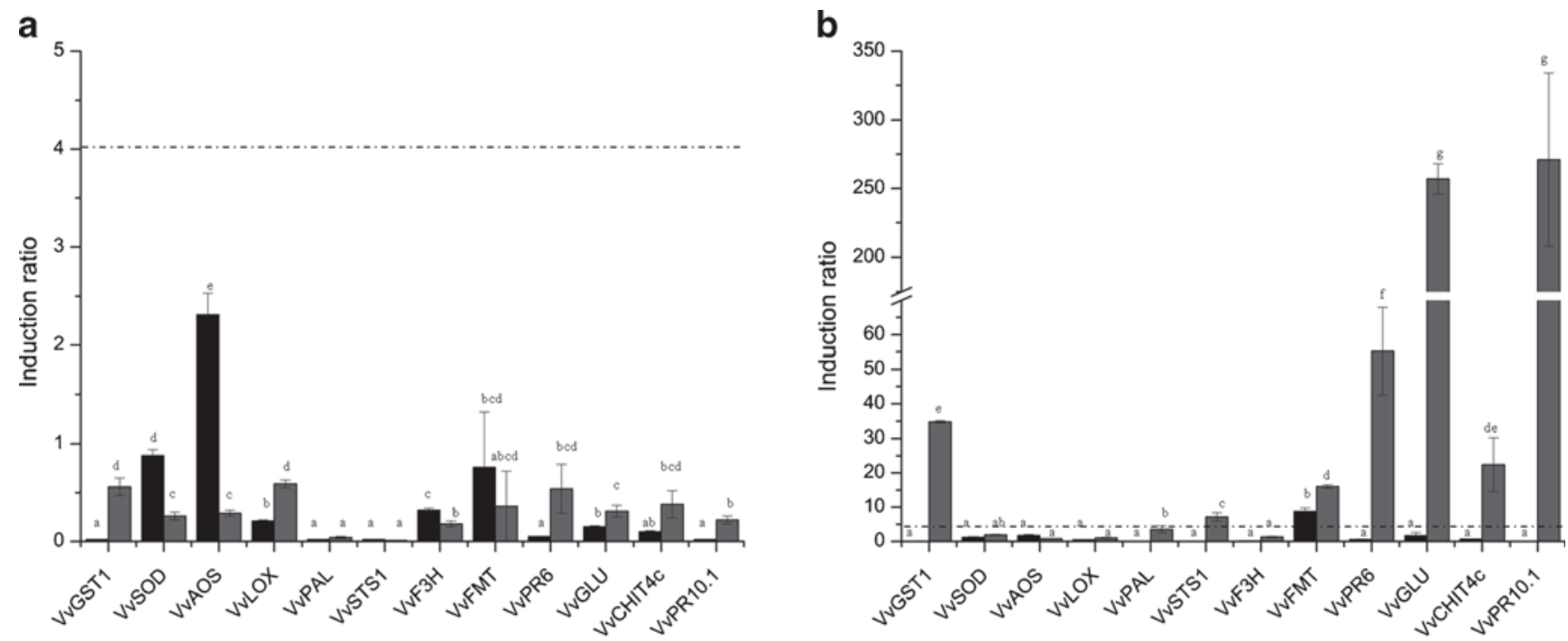

Values (means \pm STD) with dissimilar letters in the same color columns are significant at $P \leq 0.01$

Fig. 4 Defence gene expression in calli of $V$. vinifera $\mathrm{cv}$. Chardonnay subcultured in Petri dishes with 200 (A) and $500 \mu \mathrm{g} \mathrm{m} \mathrm{m}^{-1}$ (B) mellein, after 3 (black) and 6 (medium grey) days. Gene expression was assessed by RT-qPCR. The results represent relative expression in calli grown on different mellein concentrations versus those grown on malt medium (control). The genes tested encode cellular detoxification enzymes $(V v G S T 1, V v S O D)$, jasmonic acid pathway enzymes ( $V v A O S, V v L O X)$,

during the experiment, compared with higher induction by the Bt67 isolate. Furthermore, whereas the induction of defence genes increased throughout the experiment after treatment with extracellular compounds from N. parvum Bourgogne S-116, it appears that necrotic calli could establish a detoxification process ( $V v S O D$ and $V v G S T 1$, which are implicated in cellular detoxification) during the experiment. This hypothesis was confirmed by our results showing the significant induction of the $V v G S T 1$ gene during the experiment, with this isolate. With the extracellular compounds of D. seriata 98.1 and 99.7, we showed a lower induction of defence gene expression compared with $N$. parvum and a higher induction after 3 days compared with other times points. Cellular detoxification may also be established with this species because significant expression of the $V v G S T 1$ gene was detected after 3 days. These results also suggest a late and transient action of the compounds produced by this species compared to $N$. parvum, as observed on calli. To our knowledge, this is the first study of the defence genes induced by the total extracellular compounds from Botryosphaeriaceae on grapevine calli. In $V$. vinifera cv. Chardonnay, Letousey et al. (2010) also reported the induction of genes encoding enzymes implicated in the phenylpropanoid and stilbene biosynthesis pathways, as well as chitinase and detoxification enzymes in symptomatic leaves with esca disease. Valtaud et al. (2009) demonstrated substantial activation of detoxification metabolism (i.e. glutathione metabolism) in the leaves of $V$. vinifera $\mathrm{cv}$. Ugni Blanc, in response to esca infection. enzymes for secondary metabolites of the phenylpropanoid pathway $(V v P A L)$, phytoalexins pathway enzymes ( $V v S T S 1)$, flavonoid pathway enzymes $(V v F 3 H, V v F M T)$ and pathogenesis-related proteins (VvPR6, $V v G L U, V v C H I T 4 \mathrm{c}, V v P R 10.1)$. Each data point represents the mean of 3 technical and 2 biological replicates. Error bars represent the standard error of the mean. The dotted line corresponds to an induction ratio $=4$

Our results suggest the involvement of extracellular compounds from $N$. parvum and D. seriata. To understand the toxicity, we decided to evaluate whether mellein which is produced by these fungi and is described as both a characteristic toxin of Botryosphaeriaceae and a possible diagnostic marker for diseased grapevines (Andolfi et al. 2011), was responsible for the reactions observed in calli. Mellein was first reported as a toxin produced by $D$. seriata. Mellein and its derivatives are not produced by esca-associated pathogens such as Pal, Pch and Fme (Djoukeng et al. 2009). Mellein was the cause of frogeye leaf spot and black rot of apple (Venkatasubbaiah et al. 1990 and 1991) and was also produced by D. pinea, another Botryosphaeriaceae species, and caused the decline of Pinus radiata in Italy (Cabras et al. 2006). However, mellein and its derivatives seem not to be produced exclusively by botryosphaeriaceous fungi, given that other studies have also associated these compounds with non-botryosphaeriaceous fungi such as the genera Phoma, Pezicula, Septoria, Sphaeropsis and Xylaria (Cabras et al. 2006; Turner and Aldridge 1983).

Analysing the composition of the extracellular compounds reveals that the concentration of mellein produced is correlated with the amount of necrosis observed with the extracellular compounds of $N$. parvum. This suggests that mellein could be involved in the virulence of these fungi and should be considered an important phytotoxin. Tests on the effect of mellein on calli were performed to verify this hypothesis. Our results showed no necrosis on calli treated with either 25 or $200 \mu \mathrm{g} \mathrm{ml}^{-1}$ of mellein and a slight partial necrosis with the $500 \mu \mathrm{g} \mathrm{ml}^{-1}$ dose (the highest dose tested). This dose is 100 
times higher than the amounts produced by the two strains of $N$. parvum in liquid medium. Djoukeng et al. (2009) reported that mellein causes full leaf necrosis at a minimum inhibitory concentration of $3 \mu \mathrm{g} \mathrm{ml}^{-1}$, with grapevine cv. Chasselas in a leaf disc assay. These findings are in contrast to our observations regarding the toxicity of this molecule.

To complement our visual observations, we performed molecular analyses on calli, and these analyses confirmed that only the highest concentration of mellein induces a significant expression of defence genes after 6 days with two specific pathways being strongly induced by this compound: cellular detoxification $(V v G S T 1)$ and pathogenesis-related proteins (VvPR6, VvGLU, VvCHIT4c and VvPR10.1).

Our results support the conclusion that mellein, a characteristic Botryosphaeriaceae toxin, is not responsible for the toxicity of the extracellular compounds produced by the fungal isolates in our assays and could not explain the differential virulence of the fungal extracellular compounds, in the cell tests. Indeed, we have demonstrated different levels of virulence for these fungi, which depends not only on the species but also on the isolate. The extracellular compounds from $N$. parvum seemed more toxic than those produced by $D$. seriata; thus, it is possible that $D$. seriata is an endophytic fungus as described by Slippers and Wingfield (2007) and not a true pathogen of grapevine compared to $N$. parvum. Additionally, it is possible that the pathogenicity of these two fungi depends on the secretion of other types of secondary metabolites by these pathogens such as derivatives of mellein, polypeptides or exopolysaccharides (EPSs), which should also be considered. Sparapano et al. (2000) demonstrated that two naphthalenone pentaketides (scytalone and isosclerone) produced by $P$. aleophilum induced foliar symptoms similar to those shown by the esca-affected vines, after absorption at very low doses by detached leaves of grapevine, or injection into the woody tissue of shoots and branches of standing grapevines. The toxicity of the high molecular weight hydrophilic compounds produced by several fungi, identified as exopolysaccharides, has been reviewed by Evidente and Motta (2001). Indeed, work on eutypa dieback disease has shown that polypeptides secreted by E. lata participated in cell structure damage in grapevine (Octave et al. 2006). The toxic effect of the same type of compound secreted by $\mathrm{Pal}$ and $\mathrm{Pch}$ has been shown in the case of esca disease on grapevine (Luini et al. 2010). It also seems possible that there is a synergistic action between the different metabolites secreted by these fungi, but the different hypotheses still need to be clearly examined.

Acknowledgments This research was financed by CASDAR (Compte d'Affectation Spéciale au Développement Agricole et Rural), Alsace Region (France) and CIVA (Conseil Interprofessionnels des Vins d'Alsace).

\section{References}

Andolfi A, Mugnai L, Luque J, Surico G, Cimmino A, Evidente A (2011) Phytotoxins produced by fungi associated with grapevine trunk diseases. Toxins 3:1569-1605

Bertsch C, Kieffer F, Maillot P, Farine S, Butterlin G, Merdinoglu D, Walter B (2005) Genetic chimerism of Vitis vinifera cv. Chardonnay 96 is maintained through organogenesis but not somatic embryogenesis. BMC Plant Biology 5:20

Bertsch C, Ramírez-Suero M, Magnin-Robert M, Larignon P, Chong J, Abou-Mansour E, Spagnolo A, Clément C, Fontaine F (2013) Grapevine trunk diseases: complex and still poorly understood. Plant Pathol 62:243-265

Bisson M, Houeix N, Hulot C, Lacroix G, Lefevre JP, Leveque S, Magaud H, Morin A (2006) Arsenic et ses dérivés inorganiques. INERIS, fiches de données toxicologiques et environnementales des substances chimiques $77 \mathrm{p}$

Bruez E, Lecomte P, Grosman J, Doublet B, Bertsch C, Fontaine F, Ugaglia A, Teissedre PL, Da Costa JP, Guerin-Dubrana L, Rey P (2013) Overview of grapevine trunk diseases in France in the 2000s. Phytopathol Mediterr 52(2):262-275

Bruno G, Sparapano L (2006) Effects of three esca-associated fungi on Vitis vinifera L.: I. Characterization of secondary metabolites in culture media and host responses to the pathogens in calli. Physiol. Plant Mol. Pathol 69:209-223

Cabras A, Mannoni MA, Serra S, Andolfi A, Fiore M (2006) Occurrence, isolation and biological activity of phytotoxic metabolites produced in vitro by Sphaeropsis sapinea, pathogenic of Pinus radiata. Eur J Plant Pathol 115:187-193

Camps C, Kappel C, Lecomte P, Léon C, Gomès E, Coutos-Thévenot P, Delrot S (2010) A transcriptomic study of grapevine (Vitis vinifera cv. Cabernet-Sauvignon) interaction with the vascular ascomycete fungus Eutypa lata. J Exp Bot 61:1719-1737

Cristinzio G (1978) Gravi attacchi di Botryosphaeria obtusa su vite in provincia di Insernia. Informatore Fitopatologico 6:21-23

Crous PW, Gams W (2000) Phaeomoniella chlamydospora gen. et comb. nov., a causal organism of Petri grapevine decline and esca. Phytopathol Mediterr 39:112-118

Crous PW, Gams W, Wingfield MJ, van Wyk PS (1996) Phaeoacremonium gen. nov. associated with wilt and decline diseases of woody hosts and human infections. Mycologia 88:786-796

Djoukeng JD, Polli S, Larignon P, Mansour E (2009) A. Identification of phytotoxins from Botryosphaeria obtusa, a pathogen of black dead arm disease of grapevine. Eur J Plant Pathol 124:303-308

Duncan DB (1955) Multiple range and multiple F tests. Biometrics 11:141

Evidente A, Motta A (2001) Phytotoxins from fungi, pathogenic for agrarian, forestal and weedy plants. In: Tringali C (ed) Bioactive Compounds from Natural Source. Taylor \& Francis, London, pp 473-525

Evidente A, Punzo B, Andolfi A, Cimmino A, Melck D, Luque J (2010) Lipophilic phytotoxins produced by Neofusicoccum parvum, a grapevine canker agent. Phytopathol Mediterr 49:74-79

Fischer M (2002) A new wood-decaying basidiomycete species associated with esca of grapevine: Fomitiporia mediterranea (Hymenochaetales). Mycol Prog 1(3):315-324

Grosman J, Doublet B (2012) Synthèse des dispositifs d'observation au vignoble, de l'observatoire 2003-2008 au réseau d'épidémiosurveillance actuel. Phytoma- LDV 651:31-35

Hellemans J, Mortier G, De Paepe A, Speleman F, Vandesompele J (2007) qBase relative quantification framework and software for management and automated analysis of real-time quantitative PCR data. Genome Biol 8(2):R19

Larignon P (2004) Réflexions sur l'esca : Ce que l'on sait déjà montre qu'il en reste beaucoup à apprendre : Vigne. Phytoma - LDV 576:28-31. 
Larignon, $\mathrm{P}$ (2012) Maladies cryptogamiques du bois de la vigne: symptomatologie et agents pathogènes. http://wwwvignevin.com

Larignon P, Dubos B (2001) Le Black Dead Arm. Maladie nouvelle à ne pas confondre avec l'esca Phytoma 538:26-29

Larignon P, Fontaine F, Farine S, Clément C, Bertsch C (2009) Esca et Black Dead Arm: deux acteurs majeurs des maladies du bois chez la vigne. C R Acad Sci 333:765-783

Lehoczky J (1974) Black Dead-arm disease of grapevine caused by Botryosphaeria stevensii infection. Acta Phytopathologica Academiae Scientiarum Hungaricae 9:319-327

Letousey P, Baillieul F, Perrot G, Rabenoelina F, Boulay M, VaillantGaveau N, Clément C, Fontaine F (2010) Early events prior to visual symptoms in the apoplectic form of grapevine esca disease. Biochem Cell Biol 100(5):424-431

Lijavetzsky D, Almagro L, Belchi-Navarro S, Martinez-Zapater JM, Bru R, Pedreno MA (2008) Synergistic effect of methyljasmonate and cyclodextrin on stilbene biosynthesis pathway gene expression and resveratrol production in Monastrell grapevine cell cultures. BMC Res Notes 1:132

Luini E, Fleurat-Leussard P, Rousseau L, Roblin G, Berjeaud JM (2010) Inhibitory effects of polypeptides secreted by the grapevine pathogens Phaemoniella chlamydospora and Phaeoacremonium aleophilum on plant cell activities. Physiolo Mol Plant Pathol 74:403-411

Martos S, Andolfi A, Luque J, Mugnai L, Surico G, Evidente A (2008) Production of phytotoxic metabolites by five species of Botryosphaeriaceae causing decline on grapevines, with special interest in the species Neofusicoccum luteum and N. parvum. Eur J Plant Pathol 121:451-461

Mauro M, Nef C, Fallot J (1986) Stimulation of somatic embryogenesis and plant regeneration from anther culture of Vitis vinifera $\mathrm{cv}$. Cabernet-Sauvignon. Plant Cell Rep 5:377-380

Mugnai L, Graniti A, Surico G (1999) Esca (black measles) and brown wood-streaking: Two old and elusive diseases of grapevines. Plant Dis 83:404-418

Octave S, Amboradé BE, Fleurat-Leussard P, Bergès T, Roblin G (2006) Modifications of plant cell activities by polypeptides secreted by Eutypa lata, a vineyard fungal pathogen. Physiol Plant 128:103-115

Pennycook SR, Samuels GJ (1985) Botryosphaeria and Fusicoccum species associated with ripe fruit rot of Actinidia deliciosa (kiwifruit) in New Zealand. Mycotaxon 24:445-458

Péros JP, Berger G (1994) A rapid method to assess the aggressiveness of Eutypa lata isolates and the susceptibility of grapevine cultivar to Eutypa dieback. Agronomie 14:515-523

Perrin M, Gertz C, Masson JE (2004) High efficiency of regenerable embryogenic callus from anther filaments of 19-grapevine genotypes grown worldwide. Plant Sci 167:1343-1349

Petzoldt CH, Moller WJ, Sall MA (1981) Eutypa dieback of grapevine: seasonal differences in infection and duration in susceptibility of pruning wounds. Phytopathology 71:540-543

Rappaz F (1984) Les éspèces sanctionnées du genre Eutypa (Diatrypacae, Ascomycetes). Etude taxonomique et nomenclaturale Mycotaxon 20:567-586
Rovesti L, Montermini A (1987) Un deperimento della vite causato da Sphaeropsis malorum diffuso in provincia di Reggio Emilia. Informatore Fitopatologico 1:59-61

Santos C, Fragoeiro S, Phillips A (2005) Physiological response of grapevine cultivars and a rootstock to infection with Phaeoacremonium and Phaeomoniella isolates: an in vitro approach using plants and calluses. Sciencia Horticulturae 103(2):187-198

Santos C, Fragoeiro S, Valentin H, Phillips A (2006) Phenotypic characterization of Phaeoacremonium and Phaemoniella isolated from grapevines: enzyme production and virulence of extra-cellular filtrate on grapevine calluses. Sciencia Horticulturae 107:123-130

Shoemaker RA (1964) Conidial states of some Botryosphaeria species on Vitis and Quercus. Can J Bot 42:1297-1301

Slippers B, Wingfield M (2007) Botryosphaeriaceae as endophytes and latent pathogens of woody plants: diversity, ecology and impact. Fungal Biol Rev 21:90-106

Sosnowski MR, Lardner R, Wicks TJ, Scott ES (2007) The influence of grapevine cultivar and isolate of Eutypa lata on wood and foliar symptoms. Plant Dis 91:924-931

Sparapano L, Bruno G, Graniti A (2000) Effects on plants of metabolites produced in culture by Phaeoacremonium chlamydosporum. $\mathrm{P}$ aleophilum and Fomitiporia punctata Phytopatholia Mediterranea 39(1):169-177

Sparapano L, De Leonardis S, Campanella A, Bruno G (2001) Interaction between esca-associated fungi, grapevine calli and micropropagated shoot cultures of grapevine. Phytopathologia Mediterranea 40(S4): $23-428$

Spinosi J, Fevotte J (2008) Eléments techniques sur l'exposition professionnelle aux pesticides arsenicaux. Matrice cultures - expositions aux pesticides arsenicaux, Institut de veille sanitaire, http:// www.invs.sante.fr

Surico G, Mugnai L, Marchi G (2006) Older and more recent observations on esca: a critical review. Phytopathol Mediterr 45:68-86

Turner WB, Aldridge DC (1983) Fungal metabolites II. Academic Press, London, pp 82-109

Valtaud C, Foyer CH, Fleurat-Leussard P, Bourbouloux A (2009) Systemic effects on leaf glutathione metabolism and defense protein expression caused by esca infection in grapevines. Functional Plant Biol 36:260-279

Venkatasubbaiah P, Chilton WS (1990) Phytotoxins of Botryosphaeria obtusa. J Nat Prod 53:1628-1630

Venkatasubbaiah P, Sutton TB, Chilton WS (1991) Effect of phytotoxins produced by Botryosphaeria obtusa, the cause of black rot of apple fruit and frogeye leaf spot. Phytopathology 81:243-247

Wielgoss A, Kortekamp A (2006) Comparison of PR1 expression in grapevine cultures after inoculation with a host- and a non-host pathogen. Vitis 45:9-13

Yan JY, Xie Y, Zhang W, Wang Y, Liu JK, Hyde KD, Seem RC, Zhang GZ, Yao SW, Bai XJ, Dissanayake AJ, Peng YL, Li XH (2013) Species of Botryosphaeriaceae involved in grapevine dieback in China. Fungal Divers 61:221-236 